\title{
Management of the Commons for Biodiversity: Lessons from the North Pacific
}

\author{
Jerry McBeath \\ Professor of Political Science \\ University of Alaska Fairbanks \\ ffjam@uaf.edu
}

\section{Introduction}

The North Pacific ${ }^{1}$ has the world's largest groundfish fisheries, valued at more than $\$ 1$ billion annually. It also is home to the largest population of Steller sea lions (SSL), a species originating 3-4 million years ago and now endangered. The precipitous decline of the western stock of SSL in the 1970s-1990s coincided with the U.S. nationalization and exponential growth in the Gulf of Alaska (GOA) and Bering Sea/Aleutian Islands (BSAI) groundfish fishery. Believing that the fishery competed with the SSL for prey (groundfish), environmental organizations led by Greenpeace challenged the U.S. National Marine Fisheries Service (NMFS) in federal district court of Seattle; from filing of the suit, Greenpeace v. National Marine Fisheries Service, in April 1998 through March 2003, the court (and Judge Thomas S. Zilly) was the effective manager of the North Pacific commons.

The argument of the paper unfolds in four substantive parts. First, we analyze the competition of interests in the use, management, and preservation of the North Pacific commons, including the offshore and near-shore fisheries, environmental organizations, governments (federal, state, and local), and the scientific community. Second, based on the extensive court dockets in the quartet of decisions by Judge Zilly, we analyze the conflict of laws concerning management of species in the commons. We compare and contrast provisions of the National Environmental Policy Act, the Marine Mammal Protection Act, the Endangered Species Act, and the Magnuson-Stevens Act (as amended in 1996 by the Sustainable Fisheries Act).

Third, we focus on the regulatory environment in the North Pacific under American jurisdiction. We examine the structure of NMFS (now called NOAA-Fisheries) and its relationship to the North Pacific Fishery Management Council (the Council). Then, based on interviews with informants, we investigate the ways in which agency managers navigated among conflicting interests and authorities in authorizing fishery actions: establishment of Fishery Management Plans (FMPs), Acceptable Biological Catches (ABC) and Total Allowable Catches (TAC), and measures for the temporal and spatial dispersion of the fisheries. Also, we consider methods for the resolution of interest conflicts: biological assessments, biological opinions (to assess jeopardy to listed species and adverse modification of their critical habitat), and environmental impact statements.

Fourth, given the pressure on NOAA-Fisheries to conform to the mandates of both NEPA and ESA when the agency operated under court control, we investigate changes in the culture of the agency - its behavioral norms and operational codes. The question we ask is the source of changes: from the crisis itself, competition among affected interests, the product of new

\footnotetext{
${ }^{1}$ The North Pacific includes both Russian and US waters; this paper focuses on the region of the North Pacific within the 200-mile Exclusive Economic Zone (EEZ) of the United States and under federal and state of Alaska jurisdiction.
} 
scientific information as well as the role of changes in personnel. We also ask whether the changes have facilitated "better governance of natural resources."2

The Steller sea lion issue is the most controversial case in the management of the North Pacific commons, but just one in a series of national and global biodiversity conflicts. The fifth and final section of the paper distills the lessons that can be drawn from the North Pacific when interests and authorities conflict and agencies operate under conditions of uncertainty.

\section{Conflict of Interests}

Typically in biodiversity cases it is difficult to identify all interests affected by measures designed to protect endangered or threatened species. The advantage to our consideration of the SSL case is that it has been a high stakes legal proceedings in federal district court: all relevant interests were either plaintiffs, defendants, or parties that petitioned the court as amici or intervenors. Based largely on the court dockets, we describe the positions of the offshore fisheries, coastal fisheries and communities, Native subsistence interests, environmental nongovernmental organizations (ENGOs), governments, and the "scientific community."

The Offshore Fisheries. The perceived primary threat to Steller sea lions is the large ocean-going trawl fleet, which has a clear economic interest in the North Pacific groundfish fishery. In fact the trawl fleet needs to be differentiated by capitalization, ownership, gear type, and species harvested. About 7 Seattle-based corporations own and operate 22 at-sea catching and processing (trawl) vessels, around 300 feet in length. The vessels, costing from $\$ 20$ to $\$ 50$ million each, fish for pollock primarily in the Bering Sea/Aleutian Islands (BSAI) groundfish fishery. They employ 4,000 people with annual wages and benefits of approximately $\$ 108$ million. Unprocessed value of this sector is about \$200 million annually, and the processed value exceeds $\$ 550$ million annually. ${ }^{3}$ The fleet produces surimi (a fish paste used to produce artificial crab and shrimp), most of which is sold to Japan; fillets for the US market used in fish and chips and fish sandwiches (sold by fast food restaurants such as McDonald's, Burger King, and Long John Silver); and minced fish, fish meal and pollock roe. This sector of the industry is represented politically and legally by the At-Sea Processors Association (APA).

The second offshore interest includes owners and operators of nearly 60 catcher vessels fishing for groundfish in the BSAI and GOA. These smaller trawl vessels are called "catcher vessels" because they catch but do not process fish onboard. They are represented by a trade association, the United Catcher Boats, which accounts for about 85 percent of the combined BSAI pollock and Pacific cod catches harvested by catcher vessels, and in turn harvest over half of the Total Allowable Catch (TAC) of the BSAI pollock fishery. ${ }^{4}$ They deliver their catch primarily to shore plants and inshore floating processors, but also to "mother ships," which are processing vessels that do not have harvesting capacity of their own.

A third offshore sector pursues different groundfish: it fishes for flatfish, rockfish and other bottom fish, including Pacific cod and Atka mackerel, off Alaska's coast. Another difference is that it produces headed and eviscerated (referred to as "headed and gutted" or "H\&G") frozen product. In legal proceedings, this sector was represented by the Fishing

\footnotetext{
${ }^{2}$ See National Research Council, The Drama of the Commons, Washington, DC: 2002, p. 71

${ }^{3}$ Memorandum of Points and Authorities in Support of Motion of At-Sea Processors Association for Leave to Intervene at 4, 6, Greenpeace v. National Marine Fisheries Service (hereafter Greenpeace), 55 F.Supp.2d 1248 (docket no. 12).

${ }^{4}$ Memorandum of Authorities in Support of Motion to Intervene of United Catcher Boats at 3-4, Greenpeace (docket no. 20).
} 
Company of Alaska (FCA), a private commercial fishing company, and the Groundfish Forum, a non-profit trade association comprised of 11 fishing companies (not including FCA). ${ }^{5}$ These organizations represented nearly all participants in the flatfish fisheries and Atka mackerel fisheries in western Alaska. Because the American Fisheries Act (discussed below) excluded the $\mathrm{H} \& \mathrm{G}$ sector from the directed pollock fishery, they were not involved until later in court proceedings.

The final offshore sector includes four freezer longliner firms-Prowler LLC \& Ocean Prowler LLC, Clipper Seafood, Alaskan Leader Fisheries, and Fishermen's Finest-represented by the Pacific Cod Freezer Longliners (FLL). These firms participate in the BSAI and GOA Pacific cod fishery as fleet owners. They are catcher-processor longliner vessels that catch, process, and freeze their catch at sea. The fishery itself is conducted on the continental shelf at considerable distance (up to 4 days running for a fishing vessel) from shore side processors. About 36-40 freezer vessels participate in this fishery, at an average size of 125 feet, makng them shorter than the trawl fleet. ${ }^{6}$ Unlike the trawl fleet, this fishery is a hook-and-line (H\&L) fishery using longlines composed of a ground-line anchored on both ends on the seabed to which evenly spaced baited hooks are attached.

Notwithstanding similar economic interests in exploitation of groundfish, members of this industry clearly differ in size of vessels, gear types, location of fishery with respect to critical habitat of endangered species, and fish species harvested.

The Coastal Fishery. The commercial fishery in the North Pacific is largely owned by Lower-48 firms based in Seattle, but its employment effects in coastal areas of Alaska are large. For example, the city of Unalaska is a coastal fishing community where 90 percent of the employment depends on the fishing industry. Some 15 onshore seafood processing plants have a combined investment of over $\$ 345$ million with 7,600 in-season employees. ${ }^{7}$ In addition, 10 fishing vessels, representing a combined investment of over $\$ 80$ million participate in the fishery. The processing plants are headed by Westward Seafoods and collectively represented by their trade association, the Pacific Seafood Processors Association.

Other communities highly dependent on the groundfishery include Sand Point, King Cove, Cold Bay, False Pass, Akutan, and Nelson Lagoon, located at the western end of the Alaska Peninsula and in the eastern Aleutian islands. In this region, about 25 local vessels fish for pollock and Pacific cod in federal waters, while a greater number, about 80 vessels, fish for cod in near shore state waters. Most village residents are Aleuts, dependent on commercial fishing and increasingly dependent on the groundfishery as salmon fisheries have declined in magnitude and value. ${ }^{8}$

These communities are part of the Aleutians East Borough (discussed below).

Altogether, some 30 coastal communities in Alaska have economic stakes in the ocean fisheries and in their regulation for the purpose of protection of listed species.

Native Subsistence. For thousands of years, Alaska and Russian Natives have used the resources of the Bering Sea ecosystem (a northern extension of the North Pacific), including

\footnotetext{
${ }^{5}$ Memorandum in Support of Fishing Company of Alaska, Inc. and Groundfish Forum's Motion to Intervene at 1-3, Greenpeace (docket no. 430).

${ }^{6}$ Motion of Pacific Cod Freezer Longliners ... to Intervene and Memorandum of Points and Authorities in Support of Motion at 4-5, Greenpeace (docket no. 528).

${ }^{7}$ Reply to Plaintiff's Response to Proposed Intervenor-Defendant's Motion for Leave to Intervene as Defendant at 1, Greenpeace (docket no. 49).

${ }^{8}$ Memorandum in Support of Motion to Intervene by Aleutians East Borough at 2-3, Greenpece (docket no. 53).
} 
marine mammals, sea birds, shellfish, and fish, as sources of food, fuel and raw materials for clothing, tools, and other objects. The animals of the region have played important roles in the cultural and religious traditions of many indigenous peoples. Early federal legislation acknowledged this usage, as did binational and multilateral conventions, for example the Treaty for the Preservation and Protection of Fur Seals and Sea Otters (1911). Approximately 65,000 people, including the Aleut, Yup'ik and Inupiat peoples of the Alaska coast as well as the Koryal and Chukchi peoples along the Russian coast, are affected by broad ecosystem changes.

On several occasions during the Greenpeace v. NMFS litigation, American ENGOs spoke of the extent to which ecosystem changes adversely affected Native peoples. One year into the legal proceedings, a series of Russian individuals and groups petitioned the court to enter the case as friends of the court. They emphasized the trans-boundary nature of pressure from the groundfish fisheries, and the extent to which this threatened people in Russia as well as America. ${ }^{9}$

ENGOs-"Guardians of the Commons." Of course it is governments, particularly the federal government, which have responsibilities to protect the North Pacific commons and arbitrate among competing interests and uses. However, Greenpeace v. NMFS represents a serious challenge to government's stewardship of the North Pacific. Environmental organizations, with local and global connections, campaigned persuasively for a sustainable and ecologically diverse future.

Leading the charge was Greenpeace, the most prominent and controversial global ENGO. It claims a US membership of about $450,000^{10}$ and states a purpose of seeking to "expose global environmental problems and to find solutions for a peaceful and lasting future" as well as protect "biodiversity in all its forms and end the abuse of the oceans and fresh water." 11

American Oceans Campaign also participated in the Greenpeace suit. It is a smaller ENGO (now folded into Oceana) with a more specific agenda. It announces its commitment to "safeguarding the vitality of the oceans and our coastal waters because the well-being and sustainability of the earth is dependent upon healthy oceans." 12 The final party to the Greenpeace suit was the Sierra Club, among the oldest and largest US national ENGOs, with a membership of about 550,000. Its missions include protection of "the wild places of the earth," promotion of "responsible use of the earth's ecosystems and resources," and restoration of the "quality of the natural environment." "The Sierra Club includes protection of endangered species among its primary environmental issues.

The interest of environmental organizations in the North Pacific began in the $1980 \mathrm{~s}$. It was Greenpeace that pressured NMFS to list the SSL as threatened late in this decade. In 1992, in Greenpeace v. Franklin ${ }^{14}$, the organization challenged NMFS to adopt protective measures for SSL because of increasing concentration of the trawl fishery. Moreover, the complaints of environmental organizations went beyond protection of the SSL. They have objected to the increase in numbers and capacity of the trawl fishery, its concentration in time periods and spatial locations, and alleged that this threatened not only the SSL but other species feeding on the same prey: harbor seals, fur seals, and marine birds, which also have registered rates of

\footnotetext{
${ }^{9}$ Brief of Amici Curiae Sergei Vakhrin et al. at 3, 9, Greenpeace (docket no. 188).

${ }^{10}$ Plaintiff's complaint at 4, Greenpeace (docket no. 1).

${ }^{11}$ Ibid.

${ }^{12}$ Ibid.

${ }^{13}$ Ibid.

${ }^{14}$ See Greenpeace Action v. Franklin, 14 F.3d $1324\left(9^{\text {th }}\right.$ Cir. 1992).
} 
decline. It seems clear that in the view of environmental organizations, the stewards of the North Pacific have inadequately protected endangered species in the ecosystem as a whole.

Governments. Federal, state, and local governments also express unique interests in the North Pacific, with the federal government most deeply involved because the U.S. North Pacific largely falls within the EEZ. And all branches of the federal government participate in biodiversity controversy: the Congress authors the laws allocating the fisheries and protecting endangered species; the Department of Commerce and NOAA Fisheries develop regulations to implement the law; and the court system judges conflicts between the law and practices. Initially, the federal interest in the North Pacific was to obtain the optimum harvest of fish. Over time, this objective has changed to responsible and sustainable harvesting of fish species in an ecosystem context.

The state of Alaska has jurisdiction of the ocean to the 3-mile limit; but state fisheries and marine mammal management have effects into the federal EEZ and vice versa. When the state sought (belatedly) to enter into the Greenpeace v. NMFS proceedings in March 2003, it specified three independent reasons:

First, the State has a specific interest in the tax revenues attributable to fish that are processed or landed in the state. . . Second, the State of Alaska has a more general economic interest in a vigorous commercial fishing industry that provides income to families, especially in remote areas of coastal Alaska .... (T)he direct economic impacts to Alaska from fishing restrictions attributable to Steller sea lions is over \$100 million . .

The third state interest . . . is the interest in protecting state-managed fisheries from adverse impacts that might result from modifications in the federal fisheries. ${ }^{15}$

Local governments also have interests in the North Pacific ecosystem. One party to the Greenpeace action was the Aleutians East Borough (AEB), the municipality providing countytype local government services and facilities to six small villages at the western end of the Alaska Peninsula and in the eastern Aleutian Islands. The borough derives most of its revenue from a tax on the value of raw fish landed from the GOA and BSAI groundfish fisheries at shorebased (inshore) processing plants and by at-sea processor and mother ship operations. Too, the borough has a general interest in the welfare of its residents, most of whom are dependent on commercial fishing.

Other municipalities and non-profit intergovernmental organizations have been involved in this biodiversity issue as well. For example, the Southwest Alaska Municipal Conference, chartered to "promote sustainable economic development and improved quality of life in southwest Alaska," individuals, businesses, and communities affected adversely by closures and restrictions in groundfish fisheries of the GOA and BS.

The Scientific Community. In some recent regional and global environmental issues, for example climate change, the "epistemic" "17 or knowledge community has played a leading

\footnotetext{
${ }^{15}$ State of alaska's Motion to Intervene as Defendant and Memorandum in support of Motion at 6-8, Greenpeace (docket no. 589).

16 Southwest Alaska Municipal Conference, "Steller Sea Lion Mitigation Program: A Report on Mitigating Economic Losses in Alaska's Groundfish Fisheries due to Federal Measures to Protect the Steller Sea Lion," 2002, p. 4.

17 See Peter Haas, "Introduction: Epistemic Communities and International Policy Coordination," International Organization, Vol. 46, pp. 1-35.
} 
role in problem identification and moving issues to the public agenda. Marine scientists did alert governments to the precipitous decline of the western stock of Steller sea lions, and were persuasive in requesting the agency to change its listing to endangered in 1997. Too, scientists have reached consensus on the potential causes of SSL decline: fisheries competition, environmental change, predation, anthropogenic effects, disease, contaminants, and synergies. ${ }^{18}$

However, in 2003 the exact cause (or more likely the interrelated nature of causes) has not been established definitively. ${ }^{19}$ More specifically, scientists do not agree on whether fisheries management measures are needed to protect the SSL, because available data are inadequate. As a result, some scientists have supported the position of industry; others agree with the perspective of environmental organizations. Even within NMFS one finds no scientific consensus. In this case, then, the scientific interest is plural and not singular.

Summary. The North Pacific is a complex ecosystem because of its vast size, increasingly heavy economic pressures upon it, and the large number of fish, shellfish, sea bird, and marine mammal species it contains. The drama in the North Pacific commons, however, is provided by the competition among interests - commercial fisheries versus endangered species protection, private industry versus the public sector, international and national versus local—all in the absence of certain knowledge about the causes of species decline. The legal environment undergirding management of the North Pacific commons is equally complex.

\section{Conflict of Laws}

The North Pacific is a relatively recent addition to the territorial expanse and activities scope of the United States. The region entered American jurisdiction in 1867 with the cession of Alaska to the United States; only with the development of the Alaska offshore fisheries in the 1960s and 1970s, did the region enter national consciousness. We consider briefly national legislation pertaining to species protection, fisheries management, and environmental regulation.

Species Protection. Before the population of SSL was noticeably in decline, the Congress established a complex legal and regulatory regime for the management of marine mammals and their interaction with fisheries. The first law was the Marine Mammal Protection Act (16 U.S.C. S 1362(1)), passed by the Congress in 1972. The purpose of the act was to maintain or restore marine mammals in US federal waters to healthy levels by prohibiting the killing, hunting, or harassment of any marine mammal, irrespective of population size. ${ }^{20}$ Under this act, NMFS became the responsible government agency for management of most marine mammals, including the Steller sea lions. ${ }^{21}$ Its activities included development of plans to govern interaction between commercial fisheries and marine mammals, including issuance of commercial fisheries permits to allow for what is called the "incidental take" of marine mammals during normal fisheries operations.

\footnotetext{
${ }^{18}$ See, for example, www.afsc.noaa.gov/Stellers/hypotheses.htm

${ }^{19}$ The most recent study is by the National Research Council, Decline of the Steller Sea Lion in Alaskan Waters, Washington, DC, 2003.

${ }^{20}$ See http://www.legislative.noaa.tow/mammal $/ \mathrm{html}$ for outlines of laws related to management of marine mammals in the U.S.

${ }^{21}$ The US Fish \& Wildlife Service is responsible for management of sea otters, polar bear, and walruses. One finds no clear logic behind the assignment of these mammals (not to mention sea birds and other fish species) to US FWS instead of to NMFS.
} 
The most significant legislation affecting management of biodiversity, however, is the Endangered Species Act (ESA; 16 U.S.C. 1531), passed by the Congress with virtually no opposition in $1973 .^{22}$ Congress enacted ESA:

(T)o provide a means whereby ecosystems upon which endangered species and threatened

species may be conserved, to provide a program for the conservation of such endangered species and threatened species, and to take such steps as may be appropriate to achieve the purposes of treaties and conventions set forth in this subsection. ${ }^{23}$

ESA outlines a management process to provide for listing and protection of threatened and endangered species, ${ }^{24}$ which begins with an individual or group petition to the relevant agency (NMFS for most marine species and the Fish \& Wildlife Service for terrestrial ones).

Once a species is listed, the agency organizes a recovery team and develops a recovery plan to outline the potential causes of population decline with recommendations to promote recovery. Section 4(3) of ESA requires that "critical habitat" be designated within one year of the listing, defined as:

(A) specific geographic area that is essential for the conservation of a threatened or endangered species and that may require special management and protection . . . (It) may include an area that is not currently occupied by a species, but that will be needed for its recovery.

When critical habitat has been designated, which belatedly occurred for the SSL in 1993, more restrictive management regulations may be required to reduce adverse impacts to the species.

The most powerful section of ESA is Section 7, which calls for the consultation of all federal agencies to "insure that any action authorized or carried out by such agency is not likely to jeopardize the continued existence of any endangered species . . . or result in the destruction or adverse modification of habitat." Should a proposed action, for example authorizing a groundfishery to operate in any area of SSL decline (such as the Bering Sea or Gulf of Alaska) threaten the species, the action must be modified. The agency must consider mitigation alternatives or even abandon the action if jeopardy to the species or adverse modification to its critical habitat cannot be avoided.

Section 7 provides for a consultation process to define proposed actions regarding the species, identify and involve affected interests, and design attempts to mitigate adverse effects to the species.. In the case of NOAA Fisheries, the agency "consults with itself," as no other federal agency is involved. ${ }^{25}$ Internally, however, the proposed action is represented by NMFS' Office of Sustainable Fisheries (the "action" agency), while effects on the endangered species are judged by the Office of Protected Resources (the "expert" agency). Significantly, decisions in the consultation process must be based on the "best scientific and commercial information available," and not on the grounds of the economic or other interests affected. This provision has led to virulent conservative opposition to the ESA for the effect it has on the "taking" of private property.

\footnotetext{
${ }^{22}$ For a recent analysis of the ESA, see Jason F. Shogren and John Tschirhart, eds., Protecting Endangered Species in the United States, Cambridge, Cambridge University Press, 2001.

${ }^{23}$ The complete text of ESA can be found at: http://www.law.cornell.edu/uscode/16/1531.html.

${ }^{24}$ See Lowell Fritz and Richard Elmore, "The Threatened Status of Steller Sea lions (Eumatopias jubatus) Under the Endangered Species Act," Marine Fisheries Review 57, (2), 1995.

${ }^{25}$ NMFS does consult with the US FWS in several areas, for example, the effects of fisheries on the albatross.
} 
The final result of a formal consultation process is a biological opinion (BiOp) that indicates whether a species is in jeopardy. The authority issuing BiOps for the North Pacific is the Alaska Region of NMFS, and recently, the North Pacific Fishery Management Council (the Council) has been involved in the review of biological opinions, particularly those concerning the SSL. If the agency makes a jeopardy or adverse modification (now called JAM) finding, it must issue a "reasonable and prudent alternative (RPA)" if one is available, which provides protection for the species, before any federal action may continue. Moreover, the process can be challenged in federal court whether a finding of "no jeopardy" or "jeopardy" is made. ${ }^{26}$ The specific process to be followed in federal court is outlined in the Administrative Procedure Act, and is based entirely on the agency's administrative record (AR). ${ }^{27}$

Fisheries Management. The primary legislative authority for the management of the North Pacific fisheries was enacted in 1976. In this year, the Congress passed the Magnuson Fishery Conservation and Management Act (16 U.S.C. 1801-1882), named after Warren "Maggy" Magnuson, the Washington senator who spearheaded efforts to nationalize the fisheries off America's coasts. $^{28}$ (In 1996 the Congress amended this legislation, and because of the role that Alaska's senior senator Ted Stevens had played in national fisheries issues, the act was retitled the Magnuson-Stevens Act; we refer to it throughout as the MSA.) MSA embodied the objective of eliminating foreign competition from the 200 nautical mile $(\mathrm{nm})$ coastal zone of the U.S. and to stimulate a domestic fishing industry. This Exclusive Economic Zone (EEZ) covers waters off Alaska's coast - the longest coastline in the U.S. ${ }^{29}$ - including about 900,000 square miles, and it is operated under federal jurisdiction and the authority of the Department of Commerce, NOAA, and NMFS. Congress directed that the fisheries should be operated under the principle of maximum sustainable yield (MSY), meaning that they should follow what could be called "liberal" conservation rules: as many fish should be harvested as is consistent with sustainability of the fisheries as a whole. Congress provided for management of US fisheries by establishing in MSA eight regional fishery management councils to work with NMFS to develop Fishery Management Plans (FMPs), the objective of which was to develop a sustainable fishery.

In 1996, this act was amended significantly by the Sustainable Fisheries Act, which provided that all FMPs, amendments, and regulations must comply with ten national standards:

\footnotetext{
${ }^{26}$ Section 11(g)(1)(a) gives legal standing to any person who "may commence a civil suit on his own behalf . . to enjoin any person, including the United States ... who is alleged to be in violation" of the ESA.

${ }^{27}$ The Administrative Procedure Act (5 U.S.C. SS 702, 706) outlines the procedures under which actions of administrative agencies, such as NMFS, can be challenged in federal court. Allegations of illegal conduct by agencies customarily are filed in a US district court, and the judge makes a determination based on the AR of the agency. Although district courts are trial bodies, the determination is based on the record and is not a de novo proceedings, for example with the opportunity for either of the parties to call upon testimony by expert witnesses available for cross-examination. Important for this analysis is the fact that a judicial proceeding is not based on canons of scientific investigation, experimentation, and certainty - or, for that matter, the peer review process. Instead, judges ask whether the evidence (in this case the AR) does or does not support the complaint of illegal agency action, with interpretation conditioned by relevant judicial precedents. If the agency action does not conform to the judge's interpretation of the law, the action is ruled "arbitrary and capricious," and is remanded to the agency for correction.

${ }^{28}$ Under the international treaty called the Law of the Seas (1982), all nations were authorized to control the oceans off their territorial boundaries up to 200 miles. This effectively nationalized all of the North Pacific waters, as Russia and Japan claimed ownership of remaining seas outside American jurisdiction.

${ }^{29}$ The continental shelf off Alaska in the Gulf of Alaska, Bering Sea and Aleutian Islands comprises 74 percent of the entire US continental shelf.
} 
1. Prevention of "overfishing while achieving, on a continuing basis, the optimum yield from each fishery for the United States fishing industry;"

2. Use of the "best scientific information available" in management of the fishery;

3. "(T)o the extent practicable, an individual stock of fish shall be managed as a unit throughout its range, and interrelated stocks of fish shall be managed as a unit or in close coordination;"

4. No discrimination "between residents of different states" in the allocation or assignment of fishing privileges;"

5. FMPs' "where practicable, (should) consider efficiency in the utilization of fishery resources, except that no such measure shall have economic allocation as its sole source;"

6. FMPs should "take into account and allow for variations among, and contingencies in, fisheries fishery resources, and catches;"

7. FMPs "where practicable, (should) minimize costs and avoid unnecessary duplication;"

8. FMPs "consistent with the conservation requirements of this Act [including the prevention of overfishing and rebuilding of overfished stocks, should] take into account the importance of fishery resources to fishing communities;"

9. FMPs "to the extent practicable (should) (a) minimize bycatch and (b) to the extent bycatch cannot be avoided, minimize the mortality of such bycatch;"

10. FMPs "to the extent practicable, (should) promote the safety of human life at sea.",30

The final legislative authority for the American fisheries is the American Fisheries Act (AFA), passed by the Congress in late $1998 .^{31}$ The objective of this act was to reduce competition in the North Pacific fishery (focusing specifically on the Bering Sea/Aleutian Islands fishery) in order to increase sustainability, by allocating shares among major trawl fisheries. Moreover, the act made provisions for fisheries cooperatives (evolving into Community Development Quotas [CDQs]), which has localized part of the fishery.

The act acknowledged increased capitalization and over-capacity in this bountiful fishery. By restraining competition, it sought to improve fishing practices and safety in the fisheries, rationalize business operations, reduce bycatch, and increase economic returns. The development of a cooperative management structure was designed to shift monitoring and enforcement to cooperatives and their members. ${ }^{32}$

Environmental Protection. The National Environmental Policy Act of 1969 (NEPA; 41 U.S.C. S 4332) is the first comprehensive environmental legislation enacted in the United States. At its heart is a requirement that before any major federal action is taken, significantly affecting the quality of the environment, an environmental impact statement (EIS) must be completed. The EIS must comprehensively examine potential impacts of the action on the environment, and clearly specify alternatives, with their environmental effects. Courts have treated NEPA as

\footnotetext{
30 For the full text, see National Academy of Public Administration, Courts, Congress, and Constituencies: Managing Fisheries by Default, Washington, DC: 2002, p $17 \mathrm{ff}$.

${ }^{31}$ In implementing relevant fisheries legislation, NOAA Fisheries falls under the Regulatory Flexibility Act (RFA). Passed by the Congress in 1980 and significantly amended in 1996, the RFA obliges government agencies to review all regulations to insure that they do not unduly inhibit the ability of small entities to compete. The agency's compliance with RFA is subject to judicial review.

${ }^{32}$ North Pacific Fishery Management Council, Impacts of the American Fisheries Act, Washington, DC: 2002.
} 
procedural legislation and typically have not required federal agencies to produce specific substantive outcomes, so long as alternatives are carefully considered.

Summary. One federal agency chiefly is in charge of the North Pacific ecosystem, and that is NOAA Fisheries. This agency is responsible for promotion of the fisheries, to insure that the United States attains the maximum benefit from their exploitation. The MSY principle embedded in MSA is an attempt to guard against overfishing and the depletion of fish stocks. But the mechanism of MSA focuses chiefly on single species and how each can be harvested to the advantage of economic and commercial interests. As we note below, the global control rule adopted by NMFS under MSA allows exploitation to 20 percent of the unfished biomass (and before 2001 the rule allowed exploitation to 2 percent).

NOAA Fisheries also is charged with protection of threatened and endangered species, and this complicates its mission. Unlike the MSY principle, with its focus on resource utilization, ESA embodies the precautionary principle: that the responsible agency must insure that federal actions do not bring jeopardy or adverse modification to the critical habitat of the listed species. Thus the single agency must both promote fisheries utilization and provide for species protection, which divides agency focus and attention. Moreover, NEPA requires that the agency pay attention to environmental (and thus ecosystem) effects of its actions, specifying alternative means to reduce environmental damage.

The conflict of interest is echoed in the conflict of laws concerning management of the commons in the North Pacific. We now turn to the regulatory environment, which illustrates the conflicts in the actual management of resources in the commons.

\section{The Regulatory Environment in the North Pacific}

Unlike most federal agencies, NOAA Fisheries has a dual mission. Its staff produces (or contracts for) most of the science on which management of the ecosystem is based. Second, based on this framework of knowledge, the agency develops and implements regulations by which the private sector, non-governmental organizations, and government agencies use the ecosystem. We examine the structure of the agency, the nature of the federal actions it proposes under the authority of the Secretary of Commerce, and then focus on the mechanisms of conflict resolution developed to mediate among both interest and legal conflicts. Our examples are drawn from Greenpeace v. NMFS, which illustrate the difficulties encountered by the agency under court challenge.

Structure. In the history of American government, NOAA Fisheries is a relatively new agency. NMFS' stewardship role for American fisheries includes the responsibility to review and approve or disapprove FMPs and implement and administer proposed management actions and regulations submitted by the eight regional fishery management councils. NMFS has a headquarters office in Silver spring, MD and five regional offices (and five associated regional science centers) in the: Northeast (including the Great Lakes), Southwest (including the Gulf of Mexico and Caribbean), Southwest (including Hawaii and Pacific Islands), Northwest, and Alaska.

NMFS' headquarters directs and establishes operating practices and policies that assign roles and responsibilities and set timelines for action. ${ }^{33}$ With an annual budget in 2002 of $\$ 800$ million and more than 2,500 personnel, it reviews (with the assistance of NOAA General Counsel) regional submissions for completeness and approvability. It facilitates the processing

\footnotetext{
${ }^{33}$ National Academy of Public Administration, ibid., p. 53.
} 
of management actions through public comments on proposed plans and regulations. And it promulgates final regulations in the time periods required by MSA and related statutes.

Three operational offices do most of NMFS' work: 1) Sustainable Fisheries, which works with the councils to develop FMPs; 2) Protected Resources, which manages NMFS' marine mammal protection and endangered species activities, including consultations with federal agencies on actions that might affect listed species; and 3) Habitat Conservation, which protects marine habitats and reviews actions affecting essential fish habitats. It is mostly NMFS' regional offices and associated science centers that exercise management and science responsibilities. The headquarters also has an enforcement role with 100 investigative agents and 20 enforcement (patrol) officers located throughout the United States. ${ }^{34}$

Of the eight regional councils, the North Pacific Fishery Management Council (the Council) covers the largest area, including the American North Pacific. The council structure is unique in the federal regulatory process, and was established in MSA. The councils have quasilegislative powers, as their prime function is to issue and amend FMPs, on the advice of NMFS. The North Pacific Fishery Management Council has 15 members, 11 of whom have voting power (and of these 6 are from Alaska). Voting members include the Alaska regional administrator, state officials and seven members of the public who are appointed by the Secretary of Commerce. Non-voting members include the Fish \& Wildlife Service regional director, regional Coast Guard Commander, the executive director of the Interstate Marine Fisheries Commission, and a State Department representative.

On a national basis, council members tend to represent the interests of the fishing industry, both commercial and recreational. This is perhaps to be expected, given the councils' missions to facilitate and rationally develop the fisheries following the principle of MSY. Nevertheless, during the Greenpeace court proceedings, plaintiffs charged the Council with having a pro-industry bias, and objective reviews of Councils' actions point to the perception of serious conflicts of interests. ${ }^{35}$

Unlike NMFS, which is restricted under federal law from forming advisory committees, the councils may form advisory bodies. In the case of the North Pacific Fishery Management Council, historically two advisory bodies, the Advisory Panel and the Scientific and Statistical Committee, have developed and vetted Council proposals and recommendations. A new committee, initially called the RPA (for reasonable and prudent alternative) committee and now labeled the Steller sea lion mitigation measures committee, has assisted the Council in crafting ameliorative measures to keep it and NMFS in compliance with ESA law.

Federal Actions. As mentioned, the chief action of NMFS and the "council family" is development of Fishery Management Plans (FMPs) and ancillary regulations, for example the Total Allowable Catch (TAC) that may be taken, which falls within the Acceptable Biological Catch $(\mathrm{ABC}$ ) - a ceiling providing for sustainability of the fisheries.. Currently, there are 40 FMPs in the eight councils, covering individual species, or multiple species composed of several fish stocks often harvested together. The FMPs regulate the type, means, and extent of fishery exploitation, pursuant to the ten national standards of the MSA as amended. (Amendments to FMPs follow the same process.) Once adopted by the council and approved by the Secretary of Commerce, FMPs serve as the basis for federal regulations under the Administrative Procedure Act for fisheries under federal management.

\footnotetext{
${ }^{34}$ Ibid.

${ }^{35}$ Ibid., pp. 56-58.
} 
Councils are responsible also for preparing framework actions, annual specifications, and regulations for every fishery under their authority. They determine catch quotas, allocations between different segments of the fishery, allocations of daily catch limits, seasons, and other details of the next annual fishery which must be identified annually when required under an FMP. Under MSA, councils are responsible for identifying and analyzing alternative courses of actions, selecting technical parameters (such as optimum yields and biological reference points based on the best scientific information available), accommodating public participation and comment, and compiling an administrative record for proposed actions and regulations. ${ }^{36}$

Each of these numerous actions, from development of an FMP, to amending it, to establishing a catch ceiling or TAC level, to determining temporal and spatial restrictions on a fishery, is a federal action and engages both the ESA and NEPA.

Conflict Resolution Mechanisms. Both the ESA and NEPA mention "federal actions" as triggers to relatively complex processes for the protection of the listed species or environment from harms associated with operation of the fisheries. ESA requirements under Section 7 appear straightforward: the action agency is required to consult with the expert agency for the purpose of determining whether the action will be likely to jeopardize the listed species or cause adverse modification to its critical habitat. The product of the consultation process is the biological opinion, which is just that: the judgment of the expert agency, based on the best available scientific and commercial information available to it. If JAM is likely, the expert agency must recommend reasonable and prudent alternatives (RPAs) to avoid it.

Because NMFS "consults with itself," the consultation process is less than transparent. The Office of Sustainable Fisheries (SF) plays the role of action agency, while the Office of Protected Resources (PR) acts as the expert agency. Because personnel in these offices may be adjacent to one another, there is both an informal and a formal process. Informally, the responsible SF staff member may simply notify the PR staff member that an action is unlikely to produce JAM, and in the absence of objection the consultation process stops there. If the likelihood of JAM is uncertain, either SF or PR personnel may call for a biological assessment. Finally, if it is evident that the proposed action may lead to JAM, crafting of the BiOp becomes a fully formal procedure.

The consultation process is designed to give the listed species the benefit of the doubt, and thus it embodies the precautionary principle. Yet when legal proceedings against NMFS began in the SSL controversy, the tendency of the agency had been to continue the fisheries without interruption, because of the absence of any directly measurable adverse effects on the Stellers. Too, the agency was reluctant to initiate consultation, and up to December 1998 it had not issued a biological opinion with a jeopardy finding. Thus the mechanism did not have the effect of reducing conflict, which is what prompted ENGOs to change the venue and challenge agency action in court.

The NEPA system is somewhat more formal than that for determining JAM to a listed species. It begins with an environmental assessment (EA) to determine if the federal action may have a significant impact on the environment. One possible result of this assessment is a finding-of-no-significant-impact (FONZI), when the process concludes. If, however, the action will have significant impacts, a full-scale environmental impact assessment (EIS) is required.

The EIS process is broader than that for making a biological opinion, as not only federal agencies but also state and local government agencies may be involved. Also, it is more

\footnotetext{
${ }^{36}$ Ibid., pp. 48-49.
} 
inclusive because of statutory requirements for public comment. NEPA is a weaker statute than ESA in that it does not require termination of federal action when there are environmentally malign effects. Instead, it requires the crafting of alternatives and assessment of their differential impacts.

Most EIS processes have occurred in terrestrial environments, where the environmental effects of actions are relatively easy to determine. Only two EISs had been prepared in the North Pacific before the Greenpeace challenge to NMFS, in 1979 and 1981. Often lost sight of in the controversy was the difference between terrestrial and marine environments and the nature of federal actions within them.

\section{Agency Culture}

The Alaska Region of NOAA Fisheries is a different agency in 2003 than in April, 1998 when Greenpeace et al. filed suit against the agency in Western Washington U.S. District Court. We consider the status and behavior of the agency in 1998 and next examine the quartet of decisions of Thomas S. Zilly. We view the reformed agency in 2003 and analyze the factors that appear to be responsible for change.

Agency Situation in 1998. NMFS had not been entirely unresponsive to declines in the SSL population. It listed the species as threatened in 1990 and formed the Steller Sea Lion Recovery Team (SSLRT). The agency also took three protective actions: 1) it established a 3nautical mile buffer (no transit) zone around rookeries in the Gulf of Alaska and Aleutian Islands; 2) it prohibited shooting at or near SSL; and 3) it reduced the allowable level of SSL take incidental to commercial fishing operations. Yet while the listing was in process, NMFS increased opportunities for fisheries, for example by allowing a nearly 80 percent increase in the harvest level for the pollock stock in the Gulf of Alaska. ${ }^{37}$

In the following year, prompted by a Greenpeace warning that if TAC levels were not lowered, it would seek relief in federal court, NMFS reacted by implementing further spatial and temporal restrictions in the Bering Sea/Aleutian Islands and Gulf of Alaska. New regulations included restricting pollock fishery operations (seasonal and year-round) from a 10-20 nm no trawl buffer zone around rookeries, splitting the pollock allocation between eastern and western GOA areas, and limiting the total harvest during any quarter of the season. The next year, jarred by the filing of Greenpeace Action v. Franklin (1992), NMFS began implementation of more restrictive measures, such as increasing buffer zones around select rookeries, seasonal fishing closures, and further spatial and temporal allocation of fish species. Its most significant action was the final designation of critical habitat for SSL, announced in August 1993 (58 FR 17181). This designation identified over 100 haulouts and 40 rookeries and extended offshore areas thought to be essential for foraging, reproduction, and sustainability of the SSL.

NMFS staff conducted scientific studies, which resulted in the differentiation of the eastern and western stocks of the SSL. Based on this work and population viability analyses conducted by the SSLRT itself, SSLRT reported that if current trends continued, chances of SSL extinction within 100 years ranged from 65 to 100 percent. This led to the recommendation in 1995 that the western population of SSL (west of 144 degrees west longitude, by Cape Suckling, Alaska) be upgraded to an endangered listing. Yet the listing process took over two years, and in the interim the fisheries continued to operate on a status quo basis with no significant alteration

\footnotetext{
${ }^{37}$ See Lea R. Gerber, Endangered Species Act Decision Making in the Face of Scientific Uncertainty: A Case Study of the Steller Sea Lion. (1993) (Unpublished M.S. Thesis, University of Washington).
} 
of the FMPs for the BSAI or GOA regions. In fact, in 1996 NMFS concluded in a BiOp that the current FMP did not jeopardize the species.

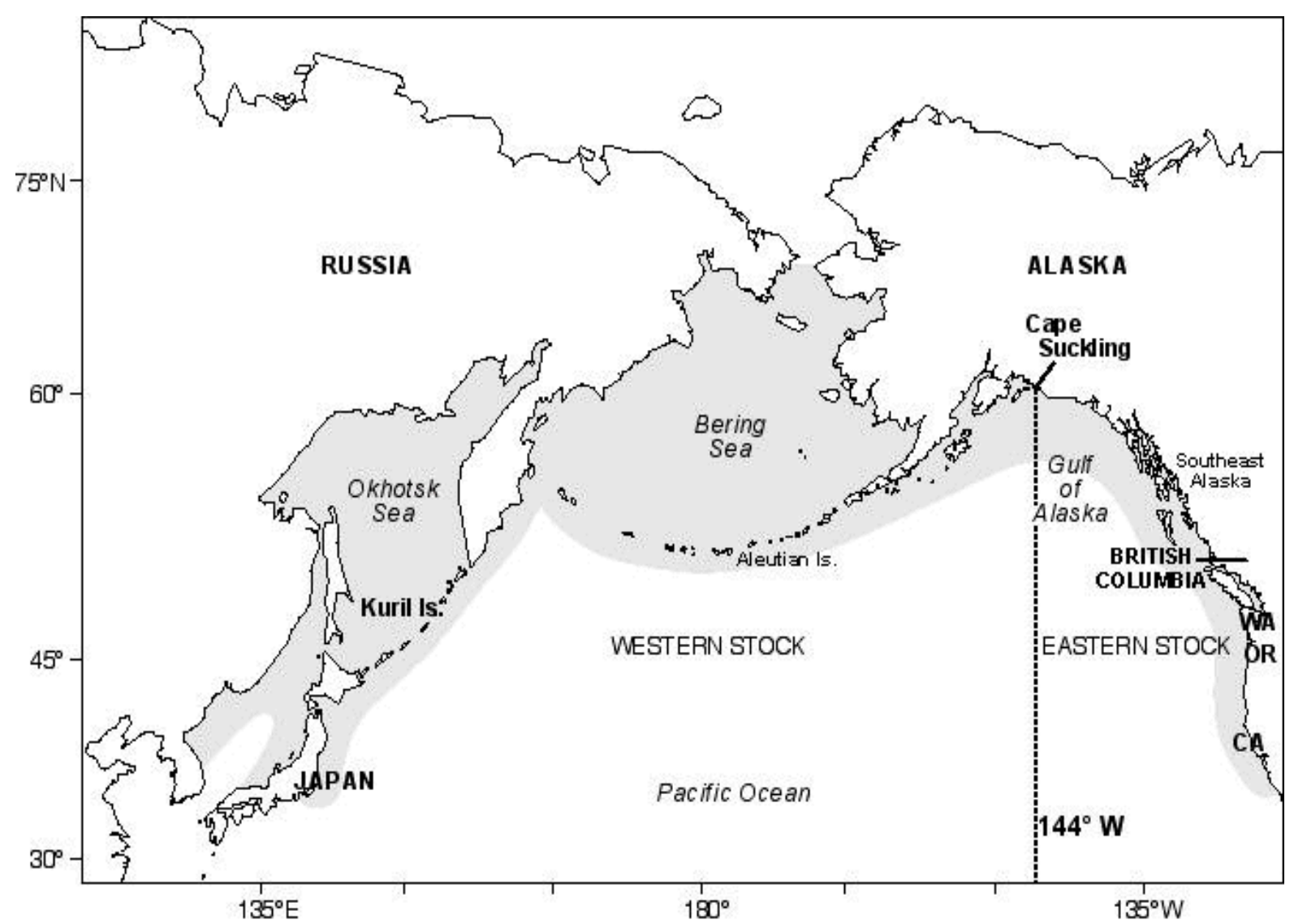

Figure 1: Map showing distribution of the Steller sea lion. Source: National Marine Mammal Laboratory: http://nmml.afsc.noaa.gov/AlaskaEcosystems/sslhom/distrib.html.

After the listing of SSL as endangered, NMFS proposed no immediate conservation measures. In December 1997 the agency accepted the Council's recommended increase of 60 percent in the western central pollock quota for the GOA (based on stock assessments) and only minor reductions in the TAC for the BSAI region. ${ }^{38}$ This is what prompted ENGOs to file action in federal court, in Greenpeace v. National Marine Fisheries Service, in April 1998.

The Zilly Quartet. On December 3, 1998, the Office of Protected Resources of NMFS issued BiOp\#1 stating that the pollock fisheries did jeopardize the recovery of the SSL in the BSAI and GOA fisheries. This was the first jeopardy opinion issued by the Alaska region and a significant shift in position of NMFS, which appears to have been the result of legal pressure from environmental organizations and increased public awareness of the SSL issue. ${ }^{39}$

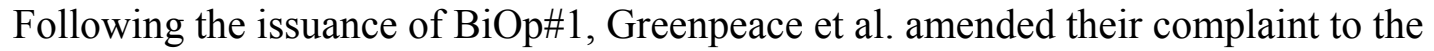
court. The environmental organizations claimed that the Atka mackerel fishery in the Aleutian Islands also jeopardized SSL recovery and that RPAs authorized by the agency fell short of protecting the SSL. NMFS and industry (which participated throughout as defendant-

${ }^{38}$ See Greenpeace, Steller Sea Lion Chronology, 2000. Also see web page at www.greenpeace.org and http://www.greenpeaceusa.org/oceans/stellerchron.html.

${ }^{39}$ For example, note coverage in the Seattle Times, August 28, 1997 and August 16, 1998; and the Anchorage Daily News, May 1, 1997 and April 16, 1998. 
intervenors) disagreed, and it was this conflict as well as the Supplemental Environmental Impact Statement (SEIS) issued by NMFS late in 1998, which Judge Zilly addressed in his first court order on July $13,1999 .{ }^{40}$ The judge upheld the jeopardy finding for the pollock fisheries and the no jeopardy finding for the Atka mackerel fishery, finding that the agency had considered relevant information and that scientific data supported the agency's conclusions. Noting that the fisheries were not the sole cause of SSL decline or the major factor preventing recovery, the judge agreed with the BiOp that the pollock fisheries were likely to jeopardize the continued existence of the SSL population. He concluded: "NMSF provided a reasonable interpretation of equivocal evidence, to which this court must defer." ${ }^{41}$

However, the judge sided with Greenpeace regarding the reasonable and prudent alternatives, implicitly faulting the Council for having weakened recommendations in the BiOp for greater temporal dispersion of the fisheries. He could not determine if the RPAs would effectively mitigate jeopardy to the SSL because the agency had not provided a reasoned explanation. The judge also ruled that NMFS had violated NEPA by failing to prepare a comprehensive SEIS. For these reasons, Judge Zilly remanded both BiOp\#1 and the SEIS to NMFS. He required the agency to prepare Revised Final Reasonable and Prudent Alternatives (RFRPAs) consistent with his order, and he effectively re-opened the environmental review process in the agency (and did so by putting NMFS on a clock: its administrator was required to make progress reports to the court every 60 days).

The second Zilly decision (Greenpeace $I I,{ }^{42}$ issued in 2000) concerned inadequacies in BiOp \#2, which NMFS promulgated on December 22, 1998. Greenpeace challenged the opinion because it did not measure the cumulative effects of the fishery - including all groundfish species - on the SSL. Greenpeace also challenged the fact that following the court's remand of BiOp \#1, NMFS "took back" BiOp \#2 and reinitiated consultation on the effects of the entire groundfish management scheme, ${ }^{43}$ thus leaving no opinion in place to govern the fishery.

The judge opined that in the context of the North Pacific fisheries, the relevant federal action was permitting the groundfishery pursuant to FMPs, and thus the ESA could be satisfied only with a comprehensive biological opinion coextensive in scope with the FMPs. He noted that $\mathrm{BiOp} \mathrm{\# 2} \mathrm{had} \mathrm{failed} \mathrm{to} \mathrm{analyze} \mathrm{critically} \mathrm{"how} \mathrm{core} \mathrm{management} \mathrm{measures} \mathrm{such} \mathrm{as} \mathrm{the}$ processes for deriving acceptable biological catch, overfishing, and total allowable catch impact endangered species." ${ }^{44}$ The judge did not fault the agency for lacking complete and certain knowledge about the impact of the fisheries on the SSL. Instead, he objected to the limited scope and quality of the agency's analysis: "NMFS entirely ignored relevant factors and admittedly failed to analyze and develop projections based on information that was available." ${ }^{, 45}$ $\mathrm{He}$ then found the agency in continuing violation of the ESA until it had a comprehensive biological opinion in place.

The judge's decision in Greenpeace II left the agency operating under RFRPAs and emergency regulations; the 2000 North Pacific groundfish fisheries continued, and a large part of them occurred within SSL critical habitat. For this reason Greenpeace sought an injunction,

\footnotetext{
${ }^{40}$ Greenpeace v. National Marine Fisheries Service (Greenpeace I), 55 F.Supp.2d 1248 (1999).

${ }^{41}$ Ibid. at 1262.

4280 F.Supp.2d 1137 (W.D. Wash. 2000).

${ }^{43}$ Defendant's Memorandum in Support of Motion to Dismiss at 2-3, Greenpeace (docket no. 286).

${ }^{44} 80$ F. Supp.2d 1137 (Greenpeace II) at 1148.

${ }^{45}$ Ibid. at 1150.
} 
specifically focusing on the harm that continued trawl fishing posed to SSL and their critical habitat.

The judge's order in Greenpeace $I I I^{46}$ noted that while the SSL population had continued to decline, approximately 24 percent between 1990 and 1998 (see figure 2), the total annual removal of groundfish in Alaska had increased exponentially during the period from the 1950s to the 1990s. ${ }^{47}$ Although there were insufficient scientific data to prove that the fisheries had caused SSL decline, nevertheless the potential adverse effects of the fisheries on the SSL has been demonstrated with "reasonable scientific certainty," and satisfied legal standards for injunctive relief. The agency clearly had violated the ESA "by authorizing the yearly fisheries in the absence of an adequate, comprehensive biological opinion."48 Thereupon the judge enjoined all groundfish trawl fishing in SSL critical habitat in the BSAI and GOA west of 144 degrees west longitude, effective August 8, 2000.

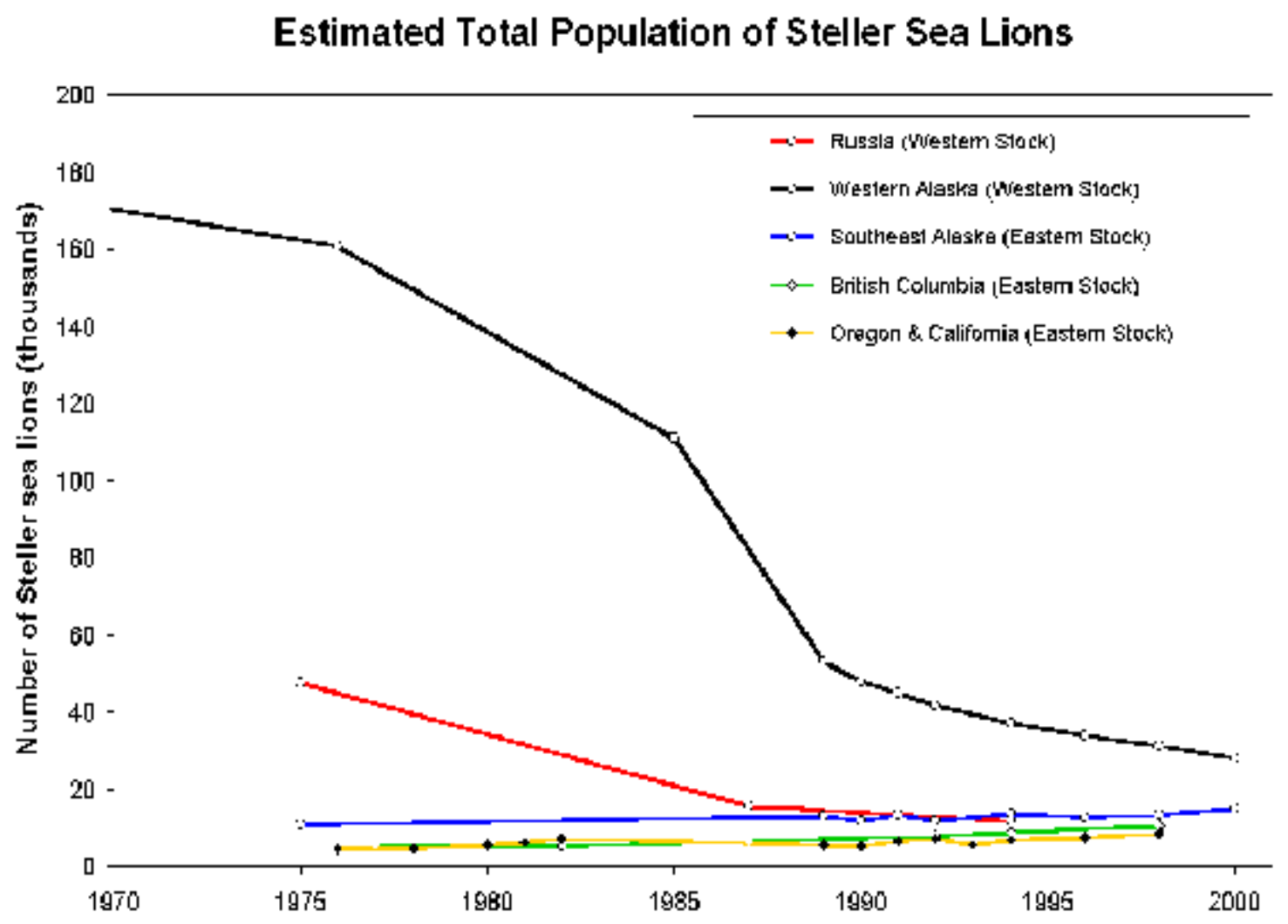

Figure 2: Dark line indicating Steller sea lion population decline of the western stock, BSAI Fishery, Alaska. Source: National Marine Mammal Laboratory of NMFS:

http://nmml.afsc.noaa.gov/AlaskaEcosystems/sslhome/decline.html

The prospect of continued closure of the fishery at the opening of the first pollock season in January 2001 mobilized the agency to prepare measure that would satisfy the court. In a

\footnotetext{
${ }^{46} 106$ F. Supp.2d 1060 (W.D. Wash. 2000), (Greenpeace III)

${ }^{47}$ Ibid. at $1070-71$.

${ }^{48}$ Ibid. at 1075.
} 
process that eventually involved the national headquarters, the agency issued a biological opinion (called the FMP BiOp) on November 30, 2000, with a jeopardy and adverse modification finding, and developed an RPA to accompany it. The judge then lifted the injunction and fishing was allowed to proceed. However, the RPA contained severe measures for the North Pacific fishery: closure of two-thirds of SSL critical habitat to all fishing for pollock, Pacific cod, and Atka mackerel, as well as strict spatial and temporal distribution rules.

Both the Council and industry objected vociferously to what they called draconian measures and immediately sought assistance from Alaska's senior senator, Ted Stevens. An industry committee prepared text for a rider which Stevens attached to the final appropriations bill as the Congress rushed to adjournment. The Clinton administration insisted on modifications to the rider, which Congress adopted on December 15, 2000. ${ }^{49}$ The final version of the rider allowed the fishery to proceed in 2001 with no more restrictions than in the early 2000 season. It mandated that the Council and agency consult and review the FMP BiOp RPA in order to develop measures to protect the SSL and its critical habitat. It allocated millions in disaster relief to coastal Alaska communities that had suffered because of near shore fishery closures and millions for scientific research into the causes of SSL decline (including a study by the National Academy of Sciences).

The Council then formed an RPA committee representing stakeholders (but heavily weighted toward industry). The committee weakened the original RPA by reopening closed areas from 10 to $20 \mathrm{~nm}$ in SSL critical habitat to fishing, and reduced or eliminated temporal and spatial dispersion measures. Meanwhile the agency reinitiated consultation on the FMP. Based on its review of six new studies and new telemetry data, the agency issued the $2001 \mathrm{BiOp}$ in October 2001, which did not reach a JAM finding. It was this BiOp as well as the FMP BiOp (still in effect as "NMFS' coverage at the plan level" ${ }^{150}$ ) which were the subject of Judge Zilly's final order in Greenpeace $I V .^{51}$

Greenpeace made three supplemental complaints concerning the biological opinions: the global fishing rate established by the agency, its new, zonal approach to mitigation within critical habitat, and the soundness of agency analysis. Greenpeace objected that the global control rule (which did not call for reduction of fishing until prey stocks fell below 40 percent of unfished levels and did not ban fishing until stocks fell to 20 percent) adversely affected the carrying capacity of the SSL critical habitat. The judge, however, ruled that ESA did not require agencies to declare a line beyond with JAM would occur, and that the 20 percent level was rational and sufficiently protective, particularly given the fact that none of the primary prey species had declined nearly that far.

The judge also accepted the agency's use of telemetry data ${ }^{52}$ to differentiate the SSL's critical habitat (which previously had been treated as though each section were of equal value to the SSL). But the judge ruled that the agency had not effectively handled bias in the method and until it did, its distinction of zones and permitting fishing in the $10-20 \mathrm{~nm}$ zone was not rational. Finally, the judge found that the agency had not provided evidence in the Administrative Record

\footnotetext{
${ }^{49}$ Consolidated Appropriations Act, 2001, Public Law \#106-554, Section 1(a)(4); 114 Stat. 2763, 2763A-176 (2000).

${ }^{50} 2001 \mathrm{BiOp}$, p. 8.

${ }^{51} 237$ F.Supp.2d 1181 (W.D. Wash. 2002), (Greenpeace IV)

${ }^{52}$ Scientists attach a small package of electronics including a satellite linked time-depth recorder to the back of SSL. The recorders transmit information on depth to an orbiting satellite, which then triangulates the source beam to estimate the SSL's location. See Administrative Record S8-549, p. 135.
} 
to support its no jeopardy/adverse modification conclusions. He remarked: "Fishing outside the forage zones may cause localized depletions within the forage zones, which could then cause adverse modification of the 'high' importance areas of critical habitat and impact the Steller sea lion." 53

Judge Zilly had no objection to the FMP BiOp, which took a highly conservative approach to fishery management in the North Pacific, in order to protect the listed species. He acknowledged the agency's expertise when it produced new data and methods in the $2001 \mathrm{BiOp}$, which created the zonal approach and allowed fishing in once prohibited areas. But because the agency had not consistently and rationally applied the new methods, and had not demonstrated in the AR that the new approaches would avoid JAM, he remanded the $2001 \mathrm{BiOp}$ to the agency to remedy the flaws. The agency completed revisions to the BiOp by June 30, 2003. Then, by mutual agreement of plaintiffs, defendants, and intervenors, the judge concluded Greenpeace $v$. National Marine Fisheries Service on April 1, 2003, shortly before the fifth anniversary of its filing.

Agency Situation in 2003. The Alaska Region of NOAA Fisheries is significantly different from its situation in 1998, in four respects: 1) compliance with NEPA and ESA are now operational objectives of the agency; 2) the agency has more personnel, with specialized expertise, to address ESA and NEPA concerns, and a larger budget to pay for them; 3) the agency's procedures and processes are more transparent; and 4) the Council now plays a greater role in environmental and endangered species issues. We discuss each change in turn.

The Greenpeace complaints addressed the failure of NMFS to comply with the National Environmental Policy Act and the Endangered Species Act, and Judge Zilly agreed that the agency had failed to demonstrate compliance. Most of the agency personnel interviewed on this project acknowledged that in 1998 little attention was paid to NEPA concerns, notwithstanding some internal discussion in the agency that work on EISs was long over-due. The agency appeared to take to heart criticism of its environmental review process, particularly provisions on public comment and development of meaningful alternatives. This lengthened the review, and the agency did not complete its draft programmatic SEIS until 2001. ${ }^{54}$ Over 21,000 comments flooded the agency on the ecosystem management scheme for the North Pacific, and the NMFS document totaled 3,300 pages. Then, before concluding the process, NMFS withdrew the document to more carefully consider environmental alternatives. The agency planned to issue the final programmatic SEIS and record of decision by late 2005, but Judge Zilly, responding to Greenpeace's complaint in 2002, required that the work be finished by September 1, 2004. Further, the agency has held numerous workshops for staff on both NEPA and ESA compliance issues.

Second, in order to meet court remands, both on NEPA and ESA issues, the agency has added personnel, including many specialized in areas of NEPA and ESA compliance. In 1998 only one staff member worked full-time on NEPA compliance issues; in 2003, the SEIS team has 25 members, and is headed by a person with specialized training in environmental impact review. The agency's budget in FY 1999, at the start of court proceedings, was $\$ 431$ million; in FY 2004, at the close of the Greenpeace case, the agency's budget was $\$ 738$ million, an increase

\footnotetext{
${ }^{53}$ Greenpeace IV at 1203.

54 The agency completed an EIS on SSL protection measures in 2001. See National Marine Fisheries Service (Alaska Region), Steller Sea Lion Protection Measures: Final Supplemental Environmental Impact Statement, Juneau, 2001.
} 
of nearly 72 percent in five years. ${ }^{55}$ Direct appropriations from the Congress to support SSL research have totaled about $\$ 83$ million alone.

Third, the agency has become more willing to allow public comment in its decisional processes. NEPA requires public notice and public comment, and the agency's work on the SEIS indicates that it has been willing to solicit comments from environmental organizations as well as industry and the general public. Agency administrator William Hogarth called for greater agency transparency in 2001, and this affected the preparation of biological opinions. The process leading to $\mathrm{BiOp} \mathrm{\# 1} \mathrm{and} \mathrm{BiOp} \mathrm{\# 2} \mathrm{in} \mathrm{late} 1998$ involved primarily personnel from the Office of Protected Resources of the Alaska Region (including the Alaska Fisheries Science Center). Preparation of the FMP BiOp in late 2000 involved teams of staff including the Juneau and Seattle staff of the agency and ultimately headquarters staff in Silver Spring, Maryland. Finally, the preparation of the $2001 \mathrm{BiOp}$ involved Alaska Region staff, members of the Council, and members of the public, because the draft BiOp was included with the draft SEIS and made available for public comment.

Fourth, since congressional intervention in the North Pacific fisheries, dating from the Stevens' rider in December, 2000, the Council (and through it the industry) has been more directly involved in both NEPA and ESA issues. Prior to 1998, the Council was not regularly informed about or consulted on preparation of environmental assessments, EISs, and biological opinions. Since the Greenpeace complaints, these matters have become agenda items for Council sessions and deliberations. Moreover, as noted, the Council formed an RPA committee in 2001 to formalize its involvement in the process of developing biological opinions. This 21member body represents stakeholders, and a majority speak for the fishing industry; yet three ENGO representatives sit on the committee, giving them some voice.

Whether these changes have transformed the culture of the agency may depend on the values of the observer. Clearly, to the most critical environmental interests, the agency remains a captive of the fishing industry, and acknowledges its responsibility in species protection only when forced to do so by the courts. Most of the participants in the SSL crisis interviewed for this study, however, believed that the agency had become more environmentally responsive, and more willing to consider eco-system impacts of the fisheries, than at any point in its history.

Factors Facilitating Agency Change. Three factors appear to have been most influential in bringing about change to the agency most responsible for the American North Pacific commons: crises, new scientific knowledge, and agency personnel and expertise.

Two decisive stages influenced the outcomes of the SSL controversy. The first was the legal challenge to NMFS by environmental organizations in April 1998. This suit precipitated a change in agency behavior leading to the December 1998 biological opinion finding that the fisheries did jeopardize the species and adversely modify its critical habitat - the first such finding in the history of the North Pacific fishery. Agency behavior had to conform to orders of the court based on interpretation of NEPA and ESA, which previously had not been among priority concerns of the agency. Indeed, some observers believe that from December 1998 to December 2000, the agency was more responsive to species protection than to fisheries enhancement values.

The second decisive stage was congressional intervention in the SSL controversy, expressed by the Stevens' rider. The rider was precipitated by the RPAs developed as part of the

\footnotetext{
${ }^{55}$ Estimates are drawn from: http://www.publicaffairs.noaa.gov/budget.htm. The FY 2004 budget is proposed, not enacted. Figures are for total agency operations, not subdivided by region.
} 
FMP BiOp, required to re-open the trawl fishery after Judge Zilly closed it in August 2000. In the words of some observers, this forced the pendulum to swing in the opposite direction, for it led to a stronger and more visible role for the Council (and industry) and efforts to mitigate JAM within the corpus of the biological opinion. Both legal and political involvement in the fisheries were crises, as they introduced unpredictable forces disrupting agency routines, and led to changes in agency behavior which otherwise would seem unlikely to have occurred, at least at that time.

A second factor influencing how the agency behaved was growth in scientific knowledge about SSL decline and the listed species' interactions with the groundfish fisheries. Marine scientists have proposed several hypotheses to explain the decline of the SSL population: nutritional stress (competition between SSL and fisheries for prey), climate regime shift, predators (killer whales), contaminants, disease, incidental take by fishermen, and hunting by Alaska Natives. However, during most of the court proceedings, nutritional stress was the prevailing hypothesis. Agency scientists used this hypothesis (and its variant, localized depletion) to alter regulation of the Atka mackerel fishery in 1997, which was the precedent for the finding that the pollock fishery jeopardized the SSL (because of the concentration of the trawl fishery).

Since 1998, scientific knowledge has improved in three areas, among others. First, scientists increasingly have drawn attention to the role that climate regime shift has played in the North Pacific, and the impact of this shift on prey composition of the SSL. Changes in ocean temperatures and currents are hypothesized to have created inhospitable conditions for fish species such as macelin and herring, which were rich nutrient prey for the SSL, while making them hospitable for pollock, sometimes referred to as "junk food." These changes, in turn, made it necessary for the SSL to forage further offshore, which may have debilitated juveniles and lactating females, the most critical cohorts for species reproduction.

Second, scientists have separated decline of the SSL western stock into two stages: the most precipitous decline in the 1970s and 1980s, and the slower decline, averaging 4-5 percent annually, of the 1990s. They have hypothesized that the steep earlier stage of decline may have been caused by high rates of incidental take and Native subsistence take, both now closely regulated, while predation by killer whales appears to be a more recent phenomenon. And in examining the nutritional health of the Stellers, they have discovered that SSL in the western stock are healthier than those in the eastern stock, where numbers have been increasing.

Third, scientists continue to advance knowledge about the behavior of Stellers, through telemetry among other methods, which have changed hypotheses about actual use of critical habitat and potential patterns of interaction with the fisheries. These data were influential in the final part of the court proceedings.

Thus, improvements in scientific knowledge had an impact on agency decisions in the SSL controversy. Yet the court did not fault the agency for lacking certain knowledge about species decline, when the law does not require certainty. What the court (and plaintiffs) complained about was the way that the agency dealt with the information it possessed, and in particular its inability to rationally and consistently defend its decisions.

A final element affecting agency behavior was the kind of personnel working for it and their expertise. Most of the research and program budget in NMFS is directed toward fisheries assessment and management in the division of Sustainable Fisheries, and the most common academic preparation of agency personnel is in fisheries biology. The agency has fewer personnel with expertise in marine mammals or in ecology. However, in 1998 the agency 
attracted to its SSL recovery position a person trained in marine mammal biology with experience working on endangered species issues. This made a critical difference in the development of biological opinions from 1998 through 2000. The National Academy of Sciences has noted the lack of diversity in backgrounds of agency personnel, and recommended that it be remedied. ${ }^{56}$

Other factors, for example, the structure of the agency and division between offices of sustainable fisheries and protected resources, likely have had impacts on behavior too.

\section{Conclusions: Lessons from the North Pacific}

From the late 1970s through the 1990s, the western population of Steller sea lions in the North Pacific declined precipitously, by almost 90 percent. The species was listed as threatened in 1990 and the western stock was reclassified to endangered in 1997; its protection is the responsibility of the National Marine Fisheries Service (now called NOAA Fisheries), under stringent requirements of the U.S. Endangered Species Act, perhaps the strongest biodiversity legislation of any nation-state. The species decline coincided with the rise of the world's largest groundfish fishery, also in the North Pacific ecosystem, with an annual value of over $\$ 1$ billion and important economic effects on Alaska coastal communities. To the present, scientists have not established the cause (or more likely the causes and their interactive effects) of species decline. Nevertheless, the prevailing scientific hypothesis at the time Greenpeace v. National Marine Fisheries Service occupied federal district court (from April 1998 through March 2003) was nutritional stress - competition of the fisheries with SSL for available prey.

We have outlined the interests at conflict in the Steller sea lion controversy: offshore fisheries, coastal fisheries, processing plants, Native subsistence users, environmental organizations acting as "guardians of the commons," governments, and a divided scientific community. The number of affected parties, the economic stakes involved (prompting congressional intervention), and the symbolic value of this ancient mega- (and some would say charismatic-) fauna altogether have made the controversy especially tense. Appeals to the law involved an additional layer of complexity, because federal statutes on fisheries management emphasize commercial development (despite the language of sustainability) while federal species and environmental protection statutes emphasize conservation.

NOAA Fisheries is the chief regulatory agency of the American North Pacific environment, and, regarding ecosystem changes, it has a dual (and conflicted) mission. Along with the Council, it develops and implements federal actions - mainly FMPs, amendments, and ancillary regulations such as TACs, spatial and temporal restrictions. The agency has mechanisms for the resolution of conflict between missions, which have not operated smoothly. During the five-year duration of Greenpeace v. NMFS, however, agency culture and behavior did change. Today, the agency is better positioned to mitigate jeopardy to endangered species than it was when legal action began.

Many lessons can be drawn from this case study of controversy in the preservation of biodiversity in the North Pacific, but we discuss only three: the role of law in biodiversity protection, the role of science, and agency capacity for change.

The Endangered Species Act is one of the most controversial environmental laws in the U.S.. The fact that it has not yet been reauthorized by the Congress is testimony of the

\footnotetext{
${ }^{56}$ See National Research Council, Science and Its Role in the National Marine Fisheries Service, Washington, DC, National Academy Press, 2002, pp. 65-66.
} 
opposition to its provisions, particularly from business and commercial interests adversely affected by it. ESA has been tested in federal courts repeatedly, but most of the challenges have concerned terrestrial species such as the Spotted Owl, in the jurisdiction of the U.S. Forest Service.

Federal courts are not an ideal venue for the resolution of issues concerning regulation of the commons. The proceedings are adversarial and do not foster compromise and accommodation. They are costly. For example, the attorneys from Earthjustice Legal Defense and Trustees for Alaska who represented the plaintiffs filed bills for nearly \$1.5 million. Outcomes are uncertain. Often the winning side prevails because of superior quality of rhetoric and not superior alignment of position to the law. And the experience, expertise, and beliefs of the judge have a weighty impact.

From the outset of the Greenpeace legal action, it was not clear how the proceedings would progress. Judge Zilly had limited experience in environmental cases (but that experience was significant as it concerned the Spotted Owl case). He was a Reagan appointee to the federal bench. Early on in the case he declined the plaintiff's request for an injunction, complying with the agency's request for more time to complete its work. Throughout he deferred to agency expertise when it made reasoned decisions, but did not hesitate to fault the agency for illogical positions, tardy actions, and inconsistent application of the data and methods it possessed. By his grasp of the complex issues, diligent questioning, and objectivity, he earned the respect of almost all participants to the controversy. None of the four Zilly orders was appealed to circuit court, and thus his interpretation becomes the relevant precedent for the evaluation of future challenges to biodiversity in the North Pacific.

The SSL controversy also is a story of the role of science, and its limitations, in biodiversity protection. Frequently in issues of environmental conflict, science informs policy, especially when the epistemic community expresses consensus about the causes and likely consequences of environmental change. However, science has not yet identified the cause of SSL decline. The most scientists have been able to do is generate hypotheses about possible causes and probable synergistic effects. And scientists are not aligned neatly on one or the other side of the controversy. In fact, each party - industry, government, ENGOs - could draw on a stable of scientific expertise to defend its preferred options.

The heart of western science is the experimental method, but because the SSL is endangered it was not possible to establish control and experimental groups, expose the latter to competition with the fisheries, and compare mortality rates over time. An approximation to the experimental method was incorporated in the FMP BiOp's RPA, but this was eliminated in the attempt to develop mitigation measures embedded in the $2001 \mathrm{BiOp}$.

Thus, science itself was not certain and replicable; it could not determine policy. On some occasions, the agency used the absence of certainty to excuse poor decisions, such as the failure to explain how RPAs would reduce jeopardy based on the principles the agency had announced. This led the judge to insist that the agency must rationally apply the principles its science had produced, and use the "best available" data. The failure of the agency lay in its logic, not its science.

Finally, the SSL controversy is a story about a bureaucratic agency and its capacity for change. NMFS began its episode in court as a well-regarded repository of knowledge about the North Pacific ecosystem. The agency is "a world leader in the development of fisheries stock 
assessment models." 57 . Too, the agency houses (and contracts for) the best information available on the Steller sea lion. But at the outset the agency was more responsive to fisheries enhancement than to its role in species preservation. It had not balanced its missions. It was perceived by environmental organizations as a "captured" agency, serving the interests of the industry it regulated, and compared by critics to the Forest Service before the Spotted Owl controversy.

NMFS did respond, albeit tardily, to evidence of species decline and executed an aboutface by its jeopardy and adverse modification finding of late 1998. The sharp learning curve described by the agency's behavior from 1998 through 2000 showed its ability to accommodate eco-system interests and values. This won it plaudits from the court and the environmental community, but provoked a violent reaction from the industry. Congressional intervention in the North Pacific fisheries through the Stevens' rider and a stronger Council role make it difficult to say whether the agency has reverted to the status quo ante (before Greenpeace v. NMFS), or is evolving in the direction taken by the Forest Service.

\section{Acknowledgments}

This article is based on the paper "Willy-Nilly Zilly? How the Court Rules the Oceans (and Steller Sea Lions)" presented to the Western Regional Science Association conference in February, 2003; it presents research in the project "Decision-Making Under Uncertainty: Management of Commercial Fisheries and Marine Mammals," partially funded by the Cooperative Institute for Arctic Research, under NOAA Cooperative Agreement no. NA 17RJ1224.. The funding agency and my collaborator, Matt Berman, are held harmless from errors of analysis and conclusions drawn in this paper. I thank the court clerks, Western District of Washington (Seattle), for assistance in locating materials in the Greenpeace v. NMFS dockets (\#C98-0492Z) from filing of the case in 1998 through June 2003. Graduate research assistant Ronald "Burr" Neely assisted this research by preparing under my direction "Steller Sea Lion Crisis: A Chronology."

A number of participants in the SSL controversy reviewed the conference paper and provided me with constructive criticism, including: Timothy Ragen, Lowell Fritz, Tamra Fairis, Jonathan Pollard, Jack Sterne, Melanie Brown, Michael Payne, Brent Paine, Eric Jorgensen, Peter Jones, Beverly Li, and Paul MacGregor. Three colleagues, Sue Hills, Sheila Fellerath, and Ian Urquhart, also reviewed the paper. I thank them all for their insights and suggestions, but am solely responsible for remaining errors and omissions.

${ }^{57}$ Ibid., p. 3. 